\title{
The Intellectual Structure of Media Literacy Field ${ }^{1}$
}

\author{
Hüseyin Özçınara*, Tuğba H. Öztürk ${ }^{b}$ \\ aPamukkale University Faculty of Education, Denizli. \\ ${ }^{\mathrm{b}}$ Ankara University \& University of the Philippines, Philippines.
}

\begin{abstract}
Media Literacy is a rich and interdisciplinary field which has roots in many different fields and scholarly perspectives such as sociology, psychology, education, political theory, communication, art, and aesthetics. There are some qualitative studies which review the media literacy literature to identify the structure and trends in the field. However, to the best of our knowledge, there are no quantitative studies which have attempted to map the field. Therefore, aim of this study is to identify the intellectual structure of the field. For this purpose, document cocitation analysis method was used aiming to reveal the shared perceptions of the authors. Apart from the qualitative methods, co-citation analysis attempts to reveal not only the perception of a particular author, but also the shared perceptions of the authors who work in that field. Therefore, regarded as an objective method enabling researchers to surface status and trends in the scientific fields, co-citation analysis is commonly used in scientific fields to examine their intellectual structure and ecology. In the present study, by adopting co-citation method, source documents were obtained from the ISI Web of Knowledge database. Results showed that the field of media literacy is fostered by seven subfields as Critical Media Literacy Education, Social Psychology, Eating Disorders, Tobacco Use, New Literacies, National and International Agendas and, Digital Citizenship and Democratic Participation. Findings of the study could be used by the researchers and educators of the field in a way of building a collective understanding of the field.
\end{abstract}

Keywords: Media Literacy; Co-citation analysis, Mapping scientific fields

\section{Medya Okuryazarlığı Alanının Kavramsal Yapısının Belirlenmesi $\ddot{O} z$}

Medya okuryazarlığı, kökleri sosyoloji, psikoloji, eğitim, politika kuramları, iletişim, sanat ve estetik gibi farkl alanlara dayanan zengin ve disiplinlerarası bir bilim alanıdır. Medya okuryazarlı̆̆ alanının yapısını ve yönelimlerini belirlemek amacıyla alanyazını nitel yöntemlerle inceleyen bazı çalışmalar bulunmaktadır. Ancak, alanın yapısını nicel yöntemlerle belirlemeye çalı̧̧an herhangi bir araştırmaya rastlanmamaktadır. Bu çalışmanın amacı, disiplinler arası bir alan olan medya okuryazarlığı alanının entellektüel yapısının ortaya konulmasıdır. Bu amaçla, alandaki araştırmacıların alana ilişkin ortak algılarını ortaya koymak için yazar ortak-atıf analizi yöntemi kullanılmıştır. Ortak atıf analizi nitel yöntemlerden farklı olarak herhangi bir araştırmacının algısını değil alanda çalışan araştırmacıların ortak algılarını yansıtır. Dolayısıyla, ortak atıf analizi bilimsel alanların yapısını ve yönelimlerini nesnel bir biçimde ortaya koymak için farklı alanlardaki araştırmacılar tarafindan kullanılmaktadır. Bu çalışmada ISI Web of Knowledge veritabanından elde edilen veriler ortak atıf analizi yöntemi ile çözümlenmiştir. Araştırma

${ }^{1}$ This study was presented in part at The Seventh International Conference Bridges of Media Education in Novi Sad, Serbia, 27-28 May 2015.

*Yazışma adresi.Email.hozcinar@pamukkale.edu.tr 
bulguları göstermektedir ki, medya okuryazarlığı alanı Eleştirel Medya Okuryazarlığı, Sosyal Psikoloji, Yeme Bozuklukları, Tütün Kullanımı, Yeni Okuryazarliklar, Ulusal ve Uluslararası Gündemler ve Dijital Vatandaşlık ve Demokratik Katılım alt alanlarından oluşmaktadır. Araştırma bulgularının, alandaki araştırmacı ve eğitimcilere alanın yapısına ilişkin bir bakış açısı sağlayacağı düşünülmektedir.

Anahtar Kelimeler: Medya Okuryazarlığı, Ortak Atıf Analizi, Bilimsel Alanların Haritalanması

\section{INTRODUCTION}

Media Literacy is a rich and interdisciplinary field which is underlined by a variety of scholarly perspectives such as sociology, psychology, education, political theory, communication, art and aesthetics. This suggests that media literacy has its roots in 'everyday context' (Goodfellow, 2011) as an embedded daily practice. In particular, borrowing from the traditional understanding of the term literacy, media literacy signifies knowledge and skills which are 'fundamental characteristics of participation in society' (Martin, 2008:155). Media, a form of communication through which the information is conveyed, covers a wide range of formats and modalities and therefore, media literacy requires individuals to posses the knowledge and skills of meaningful reading, using and producing media components. Therefore, it could be suggested that the field of media literacy is evolved by a large extension of understanding of interdisciplinary fields and semantic methods. From this point of view, it is important to bring the relevant literature together into an overarching conceptual framework that further enhances our understanding of media literacy.

An increase in the speed of technological (and sometimes social and cultural) progress in a society may suggest a profound change in the structure of scientific fields especially media literacy field which is significantly informed by the digital advancements. In that sense, it is important to map the field with its intellectual structure which in turns helps us understand an emerging field reflecting the social life.

\section{Problem of the research}

Diversifying thematic development of the field and its interdisciplinary nature require conceptual research studies dealing with identifying the intellectual structure of the media literacy and depicting conceptual framework of the literature.

In fact, although the field of media literacy has been advancing rapidly as a scientific field, yet recent studies (e.g. Jolls \& Wilson 2014) point out little understanding of foundational and basic concepts of media literacy and how these aspects have been evolved. In line with this enquiry, Potter (2010) also remarks the need of studies testing media literacy interventions and regarding this, he offers categorisations based on the media contents such as violence, health and sexual portrayals so as to organise media literacy literature. In a similar motivation, in the present research, it is aimed to map the intellectual structure of the media literacy field.

Furthermore, there are review studies dealing with media literacy by systematically utilising existing literature; however these studies are dispersed and 
usually focus on limited aspects of media literacy. In other words, studies essentially cover the subjects within subfields of media literacy rather than between the subfields. For instance, the effects of media literacy programs or interventions over the past 30 years was examined (Jeong, Cho \& Hwang, 2012), effects of health-promoting media literacy education were systematically reviewed based on the existing studies and interventions in the literature (Bergsma \& Carney, 2008); a historical review approach was taken to analyse media literacy curriculum (Friesem, Diane \& Crane, 2014). However, there is a need of conceptual study revealing intellectual structure of media literacy with its different subfields. Furthermore, aforementioned studies usually adopt meta-analysis method while this method reveals only subject patterns demonstrated by the authors of the studies. Therefore, using different methodological techniques could be helpful in demonstrating common perceptions of the authors in a way of exhibiting intellectual structure of the field. To sum up, the main aim of the present study is to find out what constitutes the media literacy field based on quantitative analysis of the literature.

\section{METHODOLOGY}

In order to provide meaningful and fundamental insights into abstract and complicated concepts such as intellectual structure of a scientific field, some metaphors such as "field of study" and "subfield" are commonly used (Small, 1999). In this context, visualising bibliometric analysis results through graph theoretical methods are helpful to clearly present intellectual structures of scientific fields as well as trends and trajectory of knowledge in these fields.

The mapping of the scientific specialties and domains may contribute to the analysis of the field sociologically or historically, leads to an increase in our comprehension about the process of information transferred among the scientific fields and the improvement of the relationship among the cognitive structures (Small \& Crane, 1979).

This study adopts a bibliometric method, Author Co-citation analysis (ACA), to examine intellectual structure of media literacy field. Bibliometrics refers to statistical analysis of written publications, such as books or articles. Bibliometrics, comprising components from mathematics, social sciences, natural sciences, engineering and even life sciences, has become a standard tool for analysing science policy and research management in the last decade (Glanzel, 2003). Bibliometrics is a method based on the assumption that "citations are an acceptable surrogate for the actual influence of various information sources on a research project" (Culnan, 1987: 342). In this context, citations help us understand the epistemic trajectories on the publications. Co-citation analysis methods provide visualizing the trajectories of clusters and identifying subfields. Thus, by using graph theoretical approaches, these tracks map essential research trends or subfields. Author co-citation analysis method has been often used since 1980s for the purpose of intellectual mapping in different fields and its validity and reliability is recognised (Nerur, Rasheed \& Natarajan, 2008). 
There are also different research methods (e.g. literature reviews, Delphi studies) which enable the researchers to study the intellectual structure of scientific fields. However, these methods heavily rely on perceptions of particular authors. Cocitation analysis reveals the structure of a domain, and unlike other similar methods, it does not attempt to reveal perception of a particular author, rather shared perceptions of all authors work in that domain. Therefore, it can be regarded as a more objective method when compared to other methods, including literature reviews (Culnan, 1987).

In an author co-citation analysis, the number of times (n) two authors are included in the references of different documents is considered as a measure for the similarity in the research perspectives of these two authors or in their theoretical perspectives. Here, " $n$ " is used as a type of measure to assess similarities between two authors' perspectives. When a raw co-citation matrix, showing co-citation numbers between authors included in a research study, is produced, authors who share the same research interest are grouped by using some statistical methods such as cluster analysis, factor analysis, multi-dimensional scaling. These groups represent subfields (McCain, 1990).

\section{Data collection}

The data used in this study were extracted from web of science. Web of science is a comprehensive and versatile web based research platform and includes major indices such as Social Science Citation Index (SSCI) and Arts and Humanities Citation Index (AHCI). In order to access publications on Media literacy, the keyword "media literacy" was searched in topic section. The results emerged from this search constitute data sets of the present research such as publications with author(s) names, titles, addresses, institutions, abstracts, references and so on. These data sets were downloaded and compiled in a text file for the next stage of analysis.

\section{Data analysis}

In this section, data analysis process was summarised in a figure below, subsequently explanations were made. Figure 1 below shows the diagrammatic display of the methodological procedures adopted in this research. 


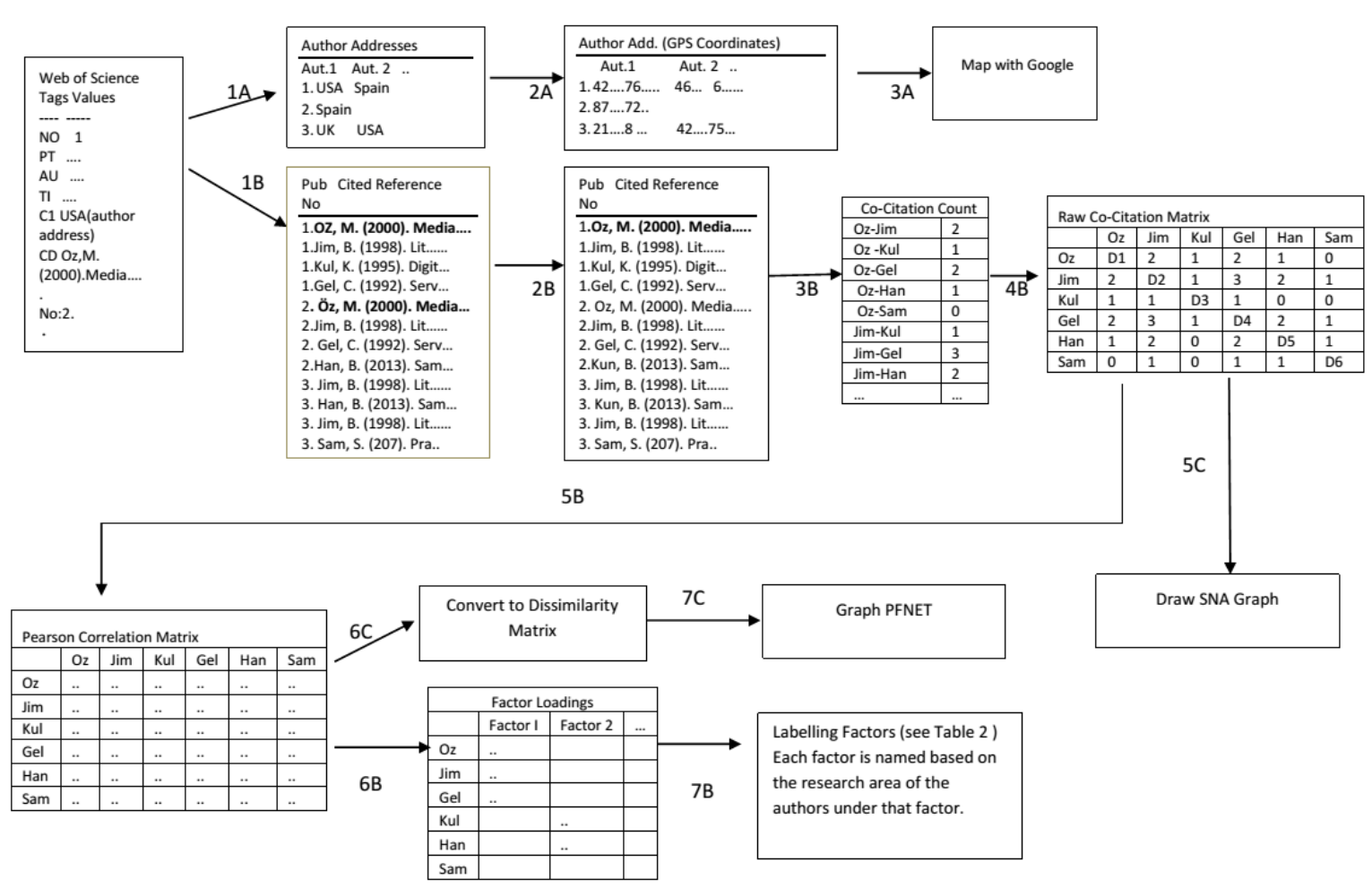

Figure 1. Diagrammatic display of the methodological procedures adopted in this research.

- 1A. Bibliometric data on publications produced from the keyword searches on the WoS were refined by using bibexcel software (Perrson, Danell \& Schneider, 2009); consequently authors' address information was compiled.

- 1B. By using Bibexcel software, bibliometric data were refined in order to access references information of these studies.

- 2A. Address information was converted to GPS coordinates.

- 2B. Authors whose names were presented differently in different studies (e.g. $\mathrm{Oz}, \mathrm{H}$.; ÖZ, H; OZ,H) were standardised. In this process, Bibexcel software was used for some operations and data were organized manually.

- 3A. GPS coordinates were marked on Google Maps. The dots pointing out addresses of co-authors were connected with lines. Thus, it was aimed to visualise academic cooperation on the map.

- 3B. By using Bibexcel software, essentially numbers of the citations of each author were identified.

Due to the likely emergence of a matrix highly consisting of number zero as a result of including all authors who are cited according to the co-citation analysis, the analysis process is limited with the mostly cited authors. Here, there is no consensus on what threshold value should be or minimum number of the authors to be included in the analysis process. However, it is observed that on examining co-citation studies, most of them include 120 authors or less. For instance, Culnan (1987), Estabrooks et al. (2008) and White \& McCain (1998) include 42, 25 and 100 authors respectively. In the 
present research, 126 authors who were cited at least 13 times were included in the data analysis process. Subsequently, co-citation numbers between these 126 mostly cited authors in media literacy studies were calculated.

- 4B. At this stage of analysis, raw co-citation matrix was produced by using cocitation numbers between authors included in the research.

- 5B. In order to normalize the data, factor analysis routine in SPSS software was used and Pearson Correlation Matrix was produced.

- 6B. Factor Analysis. Authors working on specialized domains tend to develop their own ideas based on each others' work. This, in turn, increases the likelihood of co-existence of authors working on specialized domains in the references of other publications (McCain, 1990).

In this manner, factor analysis enables us to identify authors working on specialized domains and to delineate the structure of the field by grouping the authors sharing similar research interest. As a result of factor analysis, authors sharing similar interest are loaded in the same factor. Each author's factor load is used to measure the author's level of relationship with the factor. Therefore, factors are regarded as subfields pointing out research trends and theoretical background determined by the authors' research interests presented in each factor (Nerur, Rasheed \& Natarajan, 2008). From this point of departure, at the stage of analysis demonstrated as 7B on Figure 1, Authors', whose factor load values are high, research interests and their mostly cited publications took into consideration while labelling the factors. Any factor's rate of explaining total variance could be regarded as that factor's measurement of its contribution to conceptual structure of the media literacy field. Factors which have high loading value are regarded as fundamental subfields of the related field.

In the literature, when research studies adopting co-citation methods are reviewed, it could be seen that Principal Component Analysis with varimax rotation procedure is commonly used as a basic analysis method to identify factorial structure of a field. Orthogonal (varimax) rotation method, which was used in the analysis process, runs in a way of authors' loading heavily on a particular factor; thus it helps emergence of a clear structure of the field. Factor analysis procedure is used to produce factors as much as possible but most of these factors' explanatory power is very low. Therefore, in the present research, factors were emerged based on Keiser's rule stating Eigen value should be greater than 1 .

- 6C. At this stage, PFNET graphics were produced. However, as PFNET graphics were based on dissimilarities, Pearson correlation matrix which is based on similarities was converted to dissimilarity matrix.

- 6D. In order to get a better understanding of Media literacy field, social network graph as a visual presentation was drawn based on the mostly cited authors. Graph was produced for the purpose of visualizing the similarities between the authors' research interests. In order to provide a clear structure, cocitation count threshold was set to 10 . Graphs were produced through PAJEK 
(Batagelj \& Mrvar 1998) software's spring embedded Kamada-Kawai algorithm feature.

- 7B. Factors emerged as a result of factor analysis process were labelled based on the research interests of the authors.

- 7C. First of all, pathfinder network scaling (PFNET) developed by cognitive psychologists (Schvaneveldt, Durso \& Dearholt, 1989) showing relationships between concepts is used in ACA studies to demonstrate subfields and relationships between authors. By using graph theory, Pathfinder analysis is adopted to produce PFNET graphics in order to emphasize only strongest relationships between nodes. In the scope of ACA studies, Pearson correlation coefficient symbolizes the power of relationships between authors drawing on the co-citation co-efficients and nodes represent the authors. The direct link between the authors is the most possible cost-effective link. For instance, if Author $\mathrm{A}$ and Author $\mathrm{B}$ is connected with a direct link, none of the link crossing over several nodes between $A$ and B (e.g. A to C, C to B) could be shorter than the A-B link (Nerur et al., 2008). Least-cost paths show the authors and subfields with those the authors and subfields have the strongest relation and enable simplified networks.

Dissimilarity matrix was taken as an input and PFNET graphic in relation to media literacy was produced by using PAJEK software (Batagelj \& Mrvar, 1998). The size of node is proportional with authors' citation count. Authors' placed in different factor in factor analysis is coloured differently.

\section{FINDINGS}

\section{Descriptive}

649 source documents came out as a result of searching the keywords "media literacy" on topic section of Web of Science. This source papers were cited in 20413 documents by 11552 authors. After ranking 11552 authors in numeric order based on the times they were cited in 649 source paper, co-citation matrix produced for 126 authors who were cited 13 or more times was examined in factor analysis process. On examining reference section of 649 documents published in Web of Science, it was found that Buckingham, D., Hobbs, R. and Livingstone, S. were the most cited authors (See Table 1) 
Table 1. Most cited authors in media literacy studies

\begin{tabular}{cc}
\hline Citation Count & Author \\
\hline 158 & Buckingham D \\
151 & Hobbs R \\
109 & Livingstone S \\
77 & Bandura A \\
77 & Jenkins H \\
70 & Masterman L \\
65 & Austin EW \\
64 & Potter WJ \\
64 & Aufderheide P \\
61 & Neumarksztainer D \\
\hline
\end{tabular}

16 factors explaining \%86.3 of the variance whose Eigenvalue is greater than 1 emerged as a result of factor analysis. On examining scree plot (Figure 2) in relation to factor analysis, it is observed that after the first seven factors slope of the curve starts to fall rapidly. According to the explained variance, it could be seen that the factors, following the seventh factor, account for rather low proportion of variance $(<\% 3)$. Therefore, in this section, first seven factors are named and discussed in detail. Along with this, all factors and authors are included in the graphics.

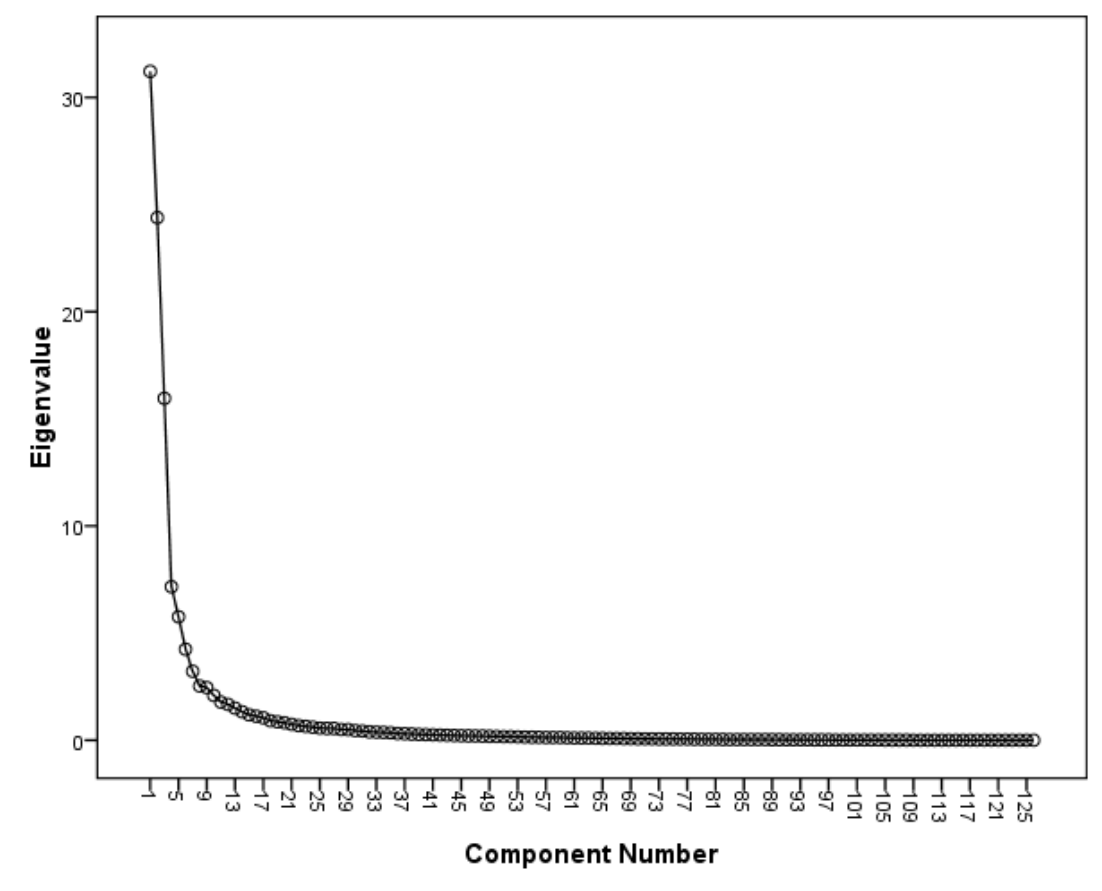

Figure 2. Scree Plot 
Table 2. Factors of the media literacy field

\begin{tabular}{lc}
\hline Factor Label & Explained Variance (\%) \\
\hline Critical Media Literacy Education & 17,914 \\
Social Psychology & 14,862 \\
Eating Disorders & 14,259 \\
Tobacco Use & 7,622 \\
New Literacies & 6,934 \\
National Agendas & 3,487 \\
Digital Citizenship and Democratic Participation & 3,112 \\
\hline
\end{tabular}

On examining results of factor analysis, the first and largest factor, Critical Media Literacy Education explained $17.9 \%$ of the variance. In this factor, 40 of them have loadings above 0.4 and 20 of them have loadings greater than 0.7. Authors as Messaris, P.,Kubey, R.,Silverblatt, A., Masterman, L., Bazalgatte, C.,Alvarado, M. and Brown, J.A. load on the factor with weights greater than 0.9 (See App. A). In this subfield, the most cited authors are Buckingham, D. and Hobbs, R.

The authors in Factor 1 focus on the Media Literacy as an emerging discipline. This factor represents explanatory knowledge about fundamentals of media literacy and how to teach media literacy. In other words, the authors mainly regard definitional issues as well as pedagogical aspects of media literacy. Some authors specifically emphasise on the word "critical". These authors focus on empowering audiences by taking a sceptical and critical look at the media texts through illustrating abstract media messages. Equipping audiences with critical analysis methods requires taking a critical pedagogy approach and this intertwined relationship between critical media literacy and critical pedagogy is visible in the publications of the authors in Factor 1. As a concrete example, rather than filtering a media message, censorship and blocking a form of communication or media texts, critical media literacy studies emphasise the importance of equipping the audience towards taking a critical stance enabling them analyse the subtle meanings. This critical stance requires to adopt critical pedagogy praxis informing audiences about power relationships, political interventions, knowledge and power.

A further topic dealt with in critical media studies concerns with empowering individuals with technical skills to enable them produce their own media contents as an alternative to main stream media. Alternative media is a good example of this.

The second factor, Social Psychology factor, accounts for \%14.9 of the variance. The results reveal that, in this factor 31 authors have factor loadings greater than 0.4 and 17 authors have factor loadings greater than 0.7. In this factor, it is seen that the authors', whose factor load is above 0.9 , basic research interests constitute subfield of media literacy such as aggression, media and child development (See App. B.).

The authors in Factor 2 focus around the issues in social psychology such as violence. They also deal with undesired psychological states such as addiction. They mainly focus on the children and adolescence due to their vulnerability (e.g. how children are affected by the media). In these studies, usually the impact of the media is 
examined through a variety of variables such as academic success, reactions of individuals exposed to violent scenes to a vulnerable individual and so on. In particular, video games as a medium and its potential effects with different parameters are examined. Different than the critical media literacy studies, these studies tend to adopt more protectionist approach to the solutions for psychological disorder caused by media contents. From this point of view, it could be reflected that concerns of the studies treat the media texts as actors and audiences as victims (e.g. addicts, children) under the influence of the texts.

Eating disorders, the third factor in explaining the variance with a weight of 14.3 $\%$, includes 22 authors and only one of the authors in this factor has factor load less than 0.7. Only authors Irving, L.M. and Story, M. have loadings above 0.4 on other factors (see App. A.). Tiggemann M. is the only author who is not in this factor but has a factor load above 0.40 on that factor. This could be clearly seen in PFNET and social network graphics. According to the PFNET graph (see App B.), eating disorders subfield is highly isolated from the main axis of media literacy field. On examining the internal structure of the subfield, it is understood that it is relatively in relation with social psychology subfield and Neumarksztainer D., Stice E. and Thompson JK constitute main axis of the field. The result of factor analysis showing these authors as the authors who have the highest loads on the factor supports the findings presented on the graphics. Social network graphic shows that (See Figure 3) Neumarksztainer and Bandura are strongly connected with co-citation ties and they bridge the two fields.

The authors in Factor 3 focus primarily on eating disorders and secondarily on body and health. In a detailed review, authors deal with the issues such as weight control, obesity, health (depression, pathology etc), predisposing factors to disordered eating such as body image and self-esteem. Like in most of the other six factors, authors focus on educational programs to protect individuals from harmful effects of the media exposure.

Wright and Leahy (2016, n.p.) and as significantly cited authors in this factor, Richardson and Paxton (2010: 115), aptly put that the relationships between media literacy and school programs on eating disorder could be described as "Most recent interventions also include or have as their main component a section on media literacy, designed again to persuade participants in the program that they are being duped by the media into accepting unrealistic ideal images"; "Content covers techniques used to manipulate media images and concepts like "appearance does not equal how valuable you are" and "the "ideal body" differs across time and between cultures".

The fourth factor, Tobacco Use, has little impact on the variance compared to the first three factors. In this subfield, there are 10 authors and 8 of them have factor loadings greater than 0.7 . The three authors who load most heavily on the factor do not load on other factors while 6 authors among the rest of the 7 authors' loadings on the first or second factors are greater than 0.3. This could be seen in PFNET and social network graphics as well. Sargent, J.D. and Brown J.D. who have loadings above 0.30 on the second and fourth factors bridge these two subfields. On examining social 
network graphs, it is seen that tobacco use subfield is perceived by the authors in the field as a subfield which is close to social psychology whereas it is also close to the critical media literacy education and eating disorders.

The authors in Factor 4 focus on tobacco use, specifically smoking, as media consumption. In some publications of these authors the issues evolve around cancer prevention, epidemiology and prevention of tobacco use. In a similar fashion to Bandura's theory is used in Social Psychology and Media studies, Icek Ajzen's theory of planned behaviour is used in exploring normative influence of media.

Interestingly, findings demonstrate eating disorders and tobacco use subfields as two separate subfields while they share the communality on health issues. On this point, it is important to consider how to interpret ACA results. According to ACA, the publications in these two factors do not share each other's underpinnings although these subfields are close. In other words, as could be seen from the Figure 3 showing SNA analysis, authors citing from the authors in eating disorders factor mostly do not cite from the authors in Tobacco Use factor. As a result of co-citation analysis, factorial structure emerges by indicating common perception of the authors whose studies are indexed by Web of Science. Further analysis on this issue is presented in the next section informed by PFNET analysis.

In the new literacies subfield, authors who load the factor most are Lankshear C, Hull G and Street BV. Jenkins H who is cited most in this subfield loads greater than 0.4 on the first and seventh factors; and greater than 0.3 on the sixth factor. In other words, Jenkins $\mathrm{H}$ bridges these subfields. On examining graphics, it could be seen that new literacies subfield is plotted relatively away from big subfields and is centred in the small subfields.

The authors in Factor 5 focus around new or multiple literacies and emergence of the media literacy in existing literacy perceptions. As in its traditional perception, the term "literacy" refers to the linguistic meaning such as how to read and write, it was observed that in the media literacy studies under Factor 5, authors tend to discuss media literacy within linguistic frameworks. For instance, in their studies, the most cited authors, Colin Lankshear, Glynda A. Hull and Brian Street et al, deal with literacy, language, and technology. Here, a further issue arises in the scope of New Literacies factor. In the same fashion to the meaning of "literacy" borrowing from the linguistic terms were discussed, it was identified that the terms "technology", "digital" and "media" are used interchangeably to describe the medium. As citing from Lanham (1995: 198), Lankshear and Knobel (2006: 12) briefly summarise the discussions as "'literacy' has extended its semantic reach from meaning 'the ability to read and write' to now meaning 'the ability to understand information however presented."' Furthermore, in the studies in Factor 5, by rooting literacy in social life practices, pedagogical issues in media literacy are discussed.

The authors in Factor 6 focus around the issues which concern a society or national issues such as policy making (e.g. children's rights in the digital age, E.U. policies on media literacy etc). Authors in this factor are mostly cited by the reports 
they produced in co-operation with some other authors. Comprehensive reports concerning national or comparative international policies implications on media literacy are cited most in Factor 6. Governmental bodies, media literacy centers and institutions are significantly cited. Usually, these reports include big data sets not only about policies and implications but also demographics about stakeholders' (e.g. parents' and children's) media literacy related information.

Finally, the authors in Factor 7, Digital Citizenship and Democratic Participation, focus around the issues such as democracy, dialogue, diversities, ethical issues and so on. Media literacy concerns the issues such as freedom of speech, peace building (e.g. it leads us to ask questions such as "who are not represented in the media; how different audiences could be affected by this media text") and valuing diversities. More specifically, some issues such as digital citizenship, democratic participation and alternative resources (the resources except from the main stream sources, big data and data journalism such as concepts and parameters which help interpreting the big data) are discussed in the cited publications.

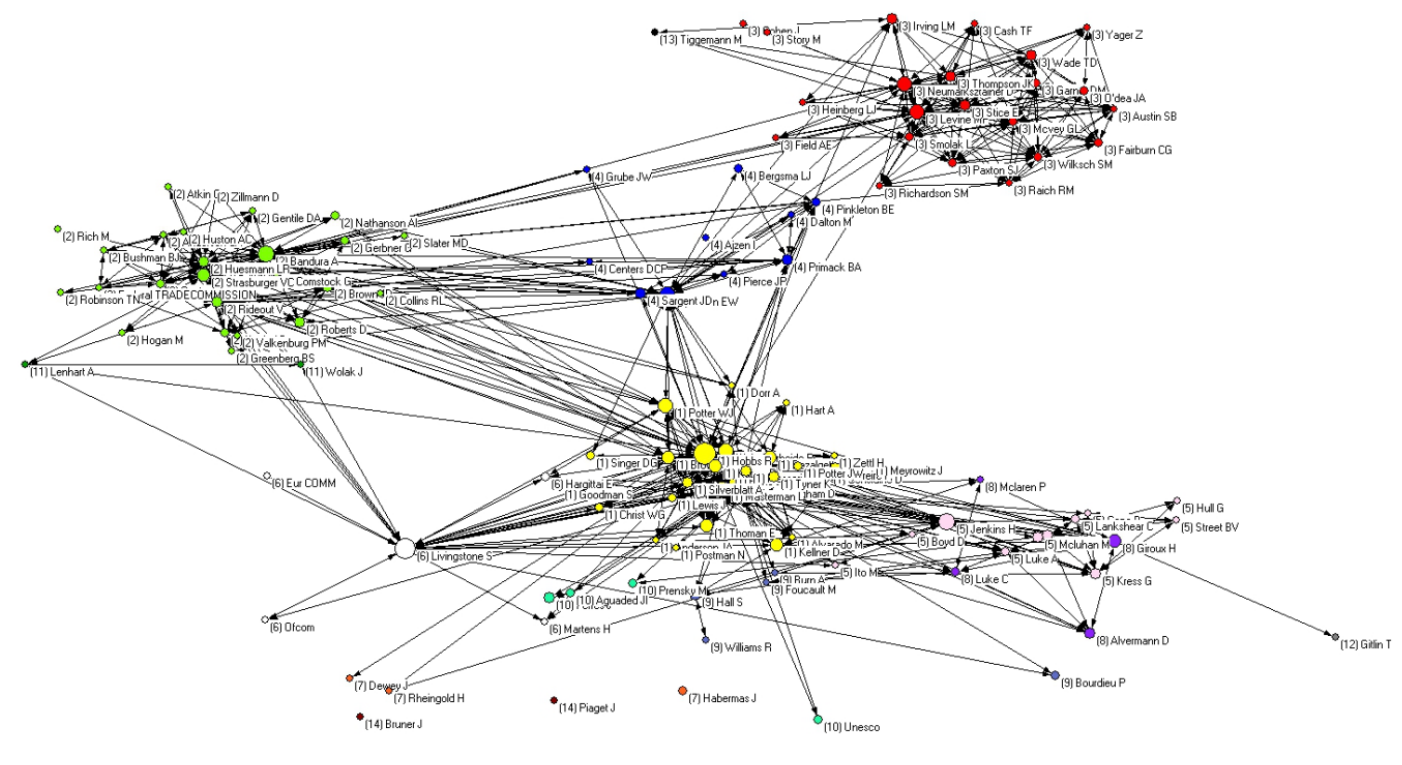

Figure 3. Social network analysis graph of author co-citations in media literacy fields (co-citation counts below 10 neglected)

In the PFNET graph above, it could be clearly seen that eating disorders (Factor 3) and tobacco use (Factor 4) subfields are both rooted in social psychology. Critical media literacy education subfield is in the center of the field and has close relationship with social psychology and other very small subfields which are not in the scope of the present study. When considering size of the nodes which is proportional to number of citations and number of the nodes (number of authors), it could be seen that publications in the first factors are considerably cited in media literacy field; in other words, these factors significantly represent the field. 


\section{CONCLUSION}

This paper has attempted to draw intellectual structure of the media literacy field. Regarding subfields of media literacy, drawing on the media content, Potter (2010: 688) categorises media literacy interventions as "violence, sexual portrayals, health, stereotypes, and fear inducing content". According to Dezuanni (2015) media literacy has been most often drawn upon socio-cultural approaches. However, in the present research, in addition to the categories and approaches in the literature, more factors including socio-psychology and health related fields as subfields of media literacy have been identified.

The emerged structure with seven factors each representing the subfield of media literacy shows that critical media literacy education is the main subfield of media literacy research. A second subfield, Social Psychology, informs most of the research subfields in media literacy field. The interaction between new literacies subfield and social psychology subfield is very weak. Compared to other fields, eating disorders subfield informs the media literacy field less. As media literacy also concerns national and international agendas, in a close examination of the cross national contributions, it is seen that most of the studies in media literacy is conducted in USA, United Kingdom and Spain. Collaboration is high between Europe and USA, while it is very rare between Asia and other parts of world.

Drawing on the literature, William (2002: 321) addresses the contested working areas in media literacy studies and he asks questions about this conceptual complexity as:

"Should students study television, radio, films, newspapers, magazines, multimedia, and the Internet? Should this study emphasize messages (Silverblatt, 2001), the context for production (Pailliotet \& Mosenthal, 2000), audiences (Buckingham 1996), or production itself (Zettl, 1998)? Should media literacy shield children from negative media influences, focus on popular texts, or have an explicit political and ideological agenda (Hobb, 1998; Kubey, 1997)? Should media literacy emphasize skills, knowledge, attitudes, or something else (Hart, 1998; Masterman \& Mariet, 1994)? Is the purpose of media literacy to inform and empower individuals or transform society?"

The results of the present research provide an answer to these questions through presenting the existing research trends based on the intellectual structure of the field that is built on.

The outcomes of the present research could enable researchers to see the subfields of the media literacy field and interaction between them. The seven emerged factors point out remarkable interdisciplinary nature of the field and this requires researchers to adopt research approach particular to media literacy. In addition to a discrete research approach, findings show that researchers in the field also need to possess the knowledge and skills of semiotics and multimodality analysis methods. As an example, Gunther Kress is one of the most cited authors and he is best known with his research on semiotics and multimodality studies. Since media inherently contains visual, auditory or textual presentations, media literacy studies require adopting 
analysis techniques different than traditional analysis techniques which are usually based upon texts (e.g. interview transcripts, documents) or quantitative data.

Moreover, this study provides a picture which shows the authors who have an important effect on the field and drawing on this information, findings illustrate different fields affecting the media literacy. This understanding would contribute to the development of the field as a cohesive field accommodating different research tendencies. Furthermore, mapping the field could help the students in media literacy to understand the field conveniently as well as helps new researchers to situate themselves in the field as a rich interdisciplinary area and to identify the most appropriate research trends for themselves.

Reflecting on the meanings of the findings for the field of media literacy, the question of why some factors supersede other issues in media literacy studies (e.g. why eating disorder supersedes topics like media ethics, digital rights) and why media literacy is highlighted in one nation while relatively ignored by other nations remain unanswered. Further studies could deal with these questions raised. Furthermore, regarding further studies, in terms of developing the present research with further cocitation studies, given that media literacy is still a newly emerged area, it was not possible to conduct a research examining the evolvement of the field in time and future research studies could detail the present research with adding time dimension. Also, this study is limited to Web of Science database and it is known that some researchers might use different database pertaining to their own country. In this respect, the present research could be widened in scope with other databases. In regard to the future studies aiming to contribute to the intellectual structure of the field, as this study presents findings based on factors emerged through adopting a specific methodological technique, more reflective studies could be carried out by pointing out interactional and relational emergence of the field within its subfields. For instance, among other factors concerning health, only tobacco use and eating disorders were identified as subfields fostering the emergence of the field, while some health related issues were significantly excluded. Further studies could be conducted to reveal out theoretical underpinnings of the field from a disciplinary perspective.

\section{REFERENCES}

Batagelj, V., \& Mrvar, A. (1998). Pajek: A program for large network analysis. Connections. 21, 47-57.

Bergsma, L. J., \& Carney, M. E. (2008). Effectiveness of health-promoting media literacy education: a systematic review. Health Education Research, 23, 522 - 542.

Culnan, M. J. (1987). Mapping the intellectual structure of MIS, 1980-1985: A co-citation analysis. Mis Quarterly, 11, 341-353.

Dezuanni, M. (2015). The building blocks of digital media literacy: sociomaterial participation and the production of media knowledge. Journal of Curriculum Studies, 47, 416-439.

Estabrooks, C. A., Derksen, L., Winther, C., Lavis, J. N., Scott, S. D., Wallin, L., \& ProfettoMcGrath, J. (2008). The intellectual structure and substance of the knowledge utilization 
field: A longitudinal author co-citation analysis, 1945 to 2004. Implementation Science,349.

Friesem, Y., Diane, Q. B., \& Crane, E. (2014). Media Now: A Historical Review of a Media Literacy Curriculum. Journal of Media Literacy Education, 6, 35 - 55.

Glanzel, W. (2003). Bibliometrics as a research field a course on theory and application of bibliometric indicators. Retrived from http://nsdl.niscair.res.in/jspui/handle/123456789/968

Goodfellow, R. (2011). Literacy, literacies and the digital in higher education. Teaching in Higher Education, 16, 131-144.

Jeong, S., Cho, H., \& Hwang, Y. (2012). Examining the Effects of Media Literacy Interventions: A Meta-Analysis. Journal of Communication, 62, 454-472.

Jolls, T., \& Wilson, C. (2014). The Core Concepts: Fundamental to Media Literacy Yesterday, Today and Tomorrow. Journal of Media Literacy Education, 6, 68 - 78.

Lankshear, C., \& Knobel, M. (2006). Digital literacy and digital literacies: Policy, pedagogy and research considerations for education. Digital Kompetanse, 1, 12-24.

Martin, A. (2008). Digital literacy and the 'Digital Society'. In The Handbook of Research on New Literacies, edited by Colin Lankshear and Michele Knobel, 151-176. New York: Peter Lang Publishing, Inc.

McCain, K. W. (1990). Mapping authors in intellectual space: A technical overview. Journal of the American society for information science, 41, 433-443.

Nerur, S. P., Rasheed, A. A., \& Natarajan, V. (2008). The intellectual structure of the strategic management field: An author co-citation analysis. Strategic Management Journal, 29, 319336. doi: 10.1002/Smj.659

Persson, O., Danell, R., \& Schneider, J. W. (2009). How to use Bibexcel for various types of bibliometric analysis. Celebrating scholarly communication studies: A Festschrift for Olle Persson at his 60th Birthday, 9-24.

Potter, W. J. (2010). The State of Media Literacy. Journal of Broadcasting and Electronic Media, 54, 675-696.

Richardson, S. M., \& Paxton, S. J. (2010). An evaluation of a body image intervention based on risk factors for body dissatisfaction: A controlled study with adolescent girls. International Journal of Eating Disorders, 43, 112-122.

Schvaneveldt, R. W., Durso, F. T., \& Dearholt, D. W. (1989). Network structures in proximity data. The Psychology of Learning and Motivation, 24, 249-284.

Small, H. (1999). Visualizing science by citation mapping. Journal of the American society for Information Science, 50, 799-813.

Small, H. G., \& Crane, D. (1979). Specialties and disciplines in science and social science: An examination of their structure using citation indexes. Scientometrics, 1, 445-461.

White, H. D., \& McCain, K. W. (1998). Visualizing a discipline: An author co-citation analysis of information science, 1972-1995. Journal of the American society for information science, 49, 327-355. 
H. Özçınar, T. H. Öztürk / Karabük University Journal of the Institute of Social Sciences, 2016, 6 (1), $162-179$

William G. C. (2002). Media literacy: Moving from the margins? Journal of Broadcasting and Electronic Media, 46, 321-327.

Wright, J., \& Leahy, D. (2016, Forthcoming). Moving Beyond Body Image: A Sociocritical Approach to Teaching About Health and Body Size Fat Pedagogy Reader. In D. Leahy, L. Burrows, J. Wright, L. McCuaig, \& D. Penny (Eds.) School Health Education in Changing Times: Curriculum, Pedagogies and Partnerships, edited by. Abingdon Oxon UK: Routledge. 


\section{H. Özçınar, T. H. Öztürk / Karabük University Journal of the Institute of Social Sciences, 2016, 6 (1), 162-179}

Appendix A. Factor analysis of top cited authors of Media Literacy field (Authors are placed in the factor on which they load most highly. Authors, having a factor load greater than 0.40 are also given in the parenthesis.)

\begin{tabular}{|c|c|c|c|c|c|c|c|c|c|c|c|c|c|}
\hline \multicolumn{2}{|c|}{ Critical Media Literacy Education } & \multicolumn{3}{|l|}{ Social Psychology } & \multicolumn{3}{|c|}{ Eating Disorders and Media } & \multicolumn{3}{|c|}{ Media and Tobacco Use } & \multicolumn{3}{|l|}{ New Literacies } \\
\hline Author Name & F Load & Author Name & \multicolumn{2}{|c|}{ F. Load } & Author Name & \multicolumn{2}{|c|}{ F.Load } & Author Name & \multicolumn{2}{|c|}{ F. Load } & Author Name & \multicolumn{2}{|c|}{ F.Load } \\
\hline Messaris P & .94 & Huesmann LR & \multicolumn{2}{|l|}{.97} & Neumarksztainer D & \multicolumn{2}{|l|}{.96} & Pierce JP & \multicolumn{2}{|l|}{.90} & Lankshear C & \multicolumn{2}{|l|}{.89} \\
\hline Kubey R & .93 & Bushman BJ & \multicolumn{2}{|l|}{.93} & Stice E & \multicolumn{2}{|l|}{.95} & Dalton $\mathrm{M}$ & \multicolumn{2}{|l|}{.89} & Hull G & \multicolumn{2}{|l|}{.87} \\
\hline Silverblatt A & .93 & Huston AC & \multicolumn{2}{|l|}{.92} & Thompson JK & \multicolumn{2}{|l|}{.93} & Primack BA & \multicolumn{2}{|l|}{.89} & Street BV & \multicolumn{2}{|l|}{.83} \\
\hline Masterman L & .92 & Anderson CA & \multicolumn{2}{|l|}{.91} & O'dea JA & \multicolumn{2}{|l|}{.92} & Sargent JD & \multicolumn{2}{|l|}{.89} & Cope B & \multicolumn{2}{|l|}{.82} \\
\hline Bazalgette C & .91 & Bandura A & \multicolumn{2}{|l|}{.90} & Mcvey GL & \multicolumn{2}{|l|}{.92} & Ajzen I & .82 & & Kress G & .82 & \\
\hline Alvarado M & .91 & Comstock G & .90 & & Levine MP & .92 & & Centers DCP & .80 & & Gee JP & .77 & \\
\hline Brown JA & .90 & Cantor J & .89 & & Wilksch SM & .91 & & Pinkleton BE & .77 & & Ito $\mathrm{M}$ & .68 & \\
\hline Anderson JA & .90 & Gentile DA & .88 & & Garner DM & .91 & & Bergsma LJ & .73 & & Luke $\mathrm{A}(8)$ & .67 & .58 \\
\hline Hobbs R & .89 & Gerbner G & .85 & & Paxton SJ & .91 & & Grube JW(4) & .70 & & Mcluhan M & .57 & \\
\hline Zettl H & .88 & Federal TR.COM & .83 & & Smolak L & .90 & & Austin EW(4) & .66 & .40 & Jenkins $\mathrm{H}(1)$ & .52 & .49 \\
\hline Meyrowitz J & .88 & Zillmann D & .83 & & Fairburn CG & .90 & & & & & Boyd D(9) & .52 & .44 \\
\hline Aufderheide P & .88 & Atkin C & .82 & & Wade TD & .90 & & & & & Digital Citizen & hip a & \\
\hline Tyner K & .88 & Roberts D & .82 & & Richardson SM & .88 & & National Ag & endas & & Democratic Pa & ticipa & tion \\
\hline Christ WG & .87 & Strasburger VC(4) & .82 & .40 & Cash TF & .85 & & Author Name & F.Lo & & Author Name & F. LC & $\mathrm{bad}$ \\
\hline Hart A & .85 & Rich M(11) & .78 & .44 & Austin SB & .84 & & Ofcom & .67 & & Dewey J & .85 & \\
\hline Buckingham D & .82 & Rideout V & .75 & .42 & Cohen J & .83 & & Eur COMM(1) & .66 & .43 & Rheingold $\mathrm{H}$ & .85 & \\
\hline Lewis J & .80 & Slater MD & .74 & .43 & Heinberg LJ & .81 & & Livingstone $S(1)$ & .63 & .60 & Habermas J & .78 & \\
\hline Potter WJ & .78 & Kunkel D(11) & .69 & .41 & Raich RM & .81 & & Martens $\mathrm{H}(1)$ & .58 & .51 & Castells M & .40 & \\
\hline Thoman E & .78 & Greenberg BS & .66 & & Yager Z & .81 & & Hargittai E(1) & .54 & .50 & & & \\
\hline Considine D & .73 & Nathanson AI (1) & .64 & .44 & Field AE & .75 & & & & & & & \\
\hline Dorr A (2) & $.59 / .57$ & Brown JD (4) & .64 & .59 & Irving LM(14) & .74 & .54 & & & & & & \\
\hline Freire $\mathrm{P}(12)$ & $.58 / .4$ & Robinson TN (13) & .64 & .51 & Story M(13) & .59 & .51 & & & & & & \\
\hline Postman N (6) & $.54 / .34$ & Hogan M(4) & .62 & .52 & & & & & & & & & \\
\hline Goodman S & .52 & Valkenburg PM(6) & .59 & .46 & & & & & & & & & \\
\hline Potter JW (6) & $.52 / .42$ & Collins RL $(4,11)$ & $.57 /$ & $54 / .44$ & & & & & & & & & \\
\hline Singer DG (2) & .51 & Baron ME & .56 & & & & & & & & & & \\
\hline Fiske J (9) & $.51 / .42$ & & & & & & & & & & & & \\
\hline Carey J & .49 & & & & & & & & & & & & \\
\hline Kellner D(8) & $.49 / .42$ & & & & & & & & & & & & \\
\hline
\end{tabular}

Appendix B. PFNET Graph with author names 
H. Özçınar, T. H. Öztürk / Karabük University Journal of the Institute of Social Sciences, 2016, 6 (1), 162-179

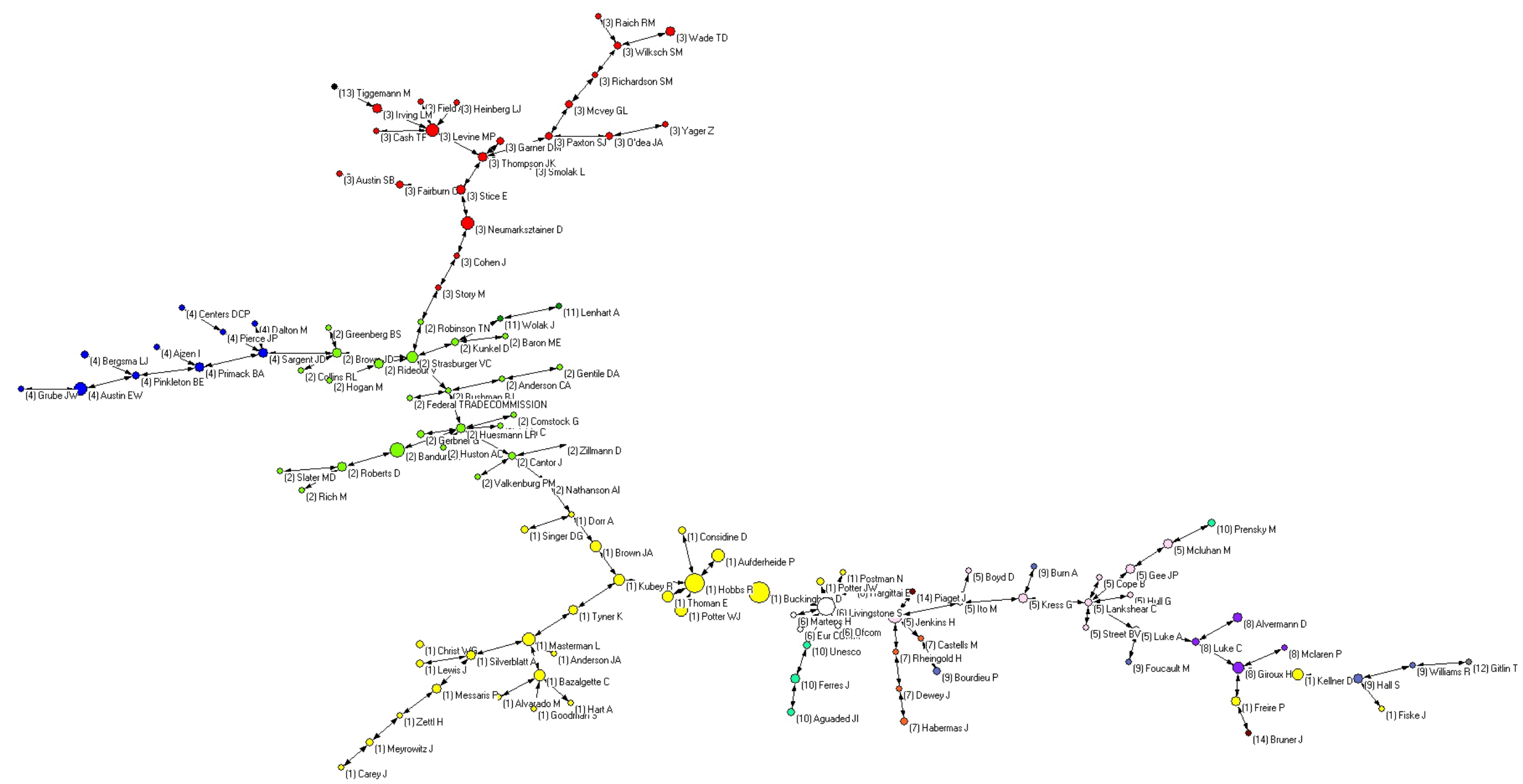

